\title{
NOTES ON THE BRYOPHYTES OF MADAGASCAR 6. EPIPHYLLOUS LIVERWORTS FROM ZAHAMENA NATIONAL PARK
}

\author{
Tamás Pócs ${ }^{1 *}$ \& Min Chuah-Petiot ${ }^{2}$ \\ ${ }^{1}$ Institute of Biology, Eszterházy Károly Catholic University, Eger, Pf. 43, Hungary, $\mathrm{H}$ - \\ 3301; 2University of Sains Malaysia, School of Biological Sciences, \\ 11800 USM PulauPenang, Malaysia; *E-mail: pocs.tamas33@gmail.com
}

\begin{abstract}
Dr. Min Chuah-Petiot, together with staff of Missouri Botanical GardenAntananarivo station, visited in 2002 the Zahamena National Park in the northeastern part of central Madagascar. They collected epiphyllous liverworts, which are deposited in TAN and a set of small duplicates were sent to Tamás Pócs for identification, which are now kept in EGR in the form of microslides. The Zahamena National Park is notorious for its high diversity of animals and vascular plants, including several endemics. But hitherto, few liverworts were collected there. This enumeration contains 28 species. None of them is new to the island, but three were known before only from their type locality (Allorgella rabenorii Tixier, Cololejeunea plagiochiliana Tixier, Cololejeunea subinflata Tixier) and eight are endemics of Madagascar or the Indian Ocean islands.
\end{abstract}

Keywords: Allorgella, Atsinanana, Cololejeunea, endemics, types

\section{INTRODUCTION}

Zahamena National Park was established in 1997, in an area of 423 square kilometres. In 2007, it became part of the "Rainforests of Atsinanana UNESCO World Heritage Site" (Wikipedia 2021). The park lies at $40 \mathrm{~km}$ distance of Ambatondrazaka town, at the border of Betsimaraha and Sihanaka Regions (Former Toamasina Province), on the eastern, windward slopes and mountain ranges of the plateau edge. The vertebrate animals and vascular plants are quite well known, including several strict endemics, but not many bryological records exist from the area as one endemic moss named Isopterygium antsihanekense Cardot. and a few thallose liverwort species as Afroriccardia somosa, Riccardia martinii, 
Riccardia ramosissima and Riccardia vohimanensis (Reeb and Gradstein 2020); Dumortiera hirsuta, Marchantia debilis and Marchantia pappeana (Reeb et al. 2018). Therefore any bryological collection made from the area is of great value.

\section{MATERIAL AND METHODS}

Min Chuah-Petiot, together with the staff of the Missouri Botanical Garden - Antananarivo station - Roger L. Andriamiarisoa, Hanta Ravololonanahary and Andriamalala Rakotondrafara made a collecting trip in the area, at 840-1010 m elevation, between 13 and 16 December 2002. They collected among others, epiphyllous liverworts and sent them for identification to the first author. The specimens are deposited in MBG (St. Louis) and TAN (Antananarivo) and some specimens of duplicates, in form of microslides, in EGR (Eger). As a result, 28 species of liverworts were identified by T. Pócs, of which three species were known before only from their type locality. The rest of species are also typical for the flora of Madagascar (Marline et al. 2012), containing several endemics. The 7 collecting localities, where epiphyllous liverworts occurred, are indicated in the enumeration in the form of the first two digits (the letters indicate more than one species from the same site).

They are all from Province de Toamasina, Préfecture Ambatondrazaka, Commune Antanandava. Environs du Parc National de Zahamena as follows:

04: Forêt ombrophile degradée. Alt. $897 \mathrm{~m}$.

06: Forêt ombrophile montagnarde. Ampelandrano. Alt. 1010 m, 17²8’47“'S, $48^{\circ} 44^{\prime} 25^{\prime \prime} \mathrm{E}$.

08: Forêt ombrophile montagnarde avec fougères arborescentes près Ampelandrano. Alt. $1000 \mathrm{~m}, 17^{\circ} 28^{\prime} \mathrm{S}, 48^{\circ} 45^{\prime} 08^{\prime \prime} \mathrm{E}$.

10: Forêt ombrophile degradée sur la terre brulée et cultivé. Alt. $1000 \mathrm{~m}$, $17^{\circ} 28^{\prime} 48^{\prime \prime} \mathrm{S}, 48^{\circ} 44^{\prime} 51^{\prime \prime} \mathrm{E}$.

11: Forêt ombrophile montagnarde peu degradée près Ampelandrano. Alt. 1000 $\mathrm{m}, 17^{\circ} 28^{\prime} 44^{\prime \prime} \mathrm{S}, 48^{\circ} 44^{\prime} 21^{\prime \prime} \mathrm{E}$.

12: Forêt ombrophile montagnarde près Ambarihely. Alt. $900 \mathrm{~m}, 17^{\circ} 28^{\prime} \mathrm{S}, 48^{\circ} 4^{\prime} \mathrm{E}$. 13: Forêt ombrophile degradée près Rivière Antranoray. Alt. 820 m, $17^{\circ} 29^{\prime} 44^{\prime \prime} \mathrm{S}$, $48^{\circ} 45^{\prime} 35^{\prime \prime} \mathrm{E}$. 


\section{RESULTS}

The enumeration below contains all species observed. Some of them (especially members of the genus Lejeunea) are not identified to the species level, either because they are in sterile state and also, because its Madagascar species are not yet taxonomically revised. The nomenclature follows Söderström et al. (2016).

Allorgella rabenorii (Tixier) G.E.Lee, Schäf.-Verw. \& Heinrichs Basionym.: Otolejeunea rabenorii Tixier (Tixier 1988).

08/151A, 09/158. A Madagascar endemic, hitherto known only from its type locality in Toamasina region, route de Lakoto (Tixier 1988).

Calypogeia annabonensis Steph.

07/096. Widespread, but uncommon tropical African species (Wigginton 2018).

Calypogeia fissa (L.) Raddi

07/107. Northern temperate species widespread also in African mountains.

Capillolejeunea mascarena S.W. Arnell (Figures 1, 4)

11/257B. Lemurian endemic known from Comoro Islands, Madagascar and Mauritius (He et al. 2014).

Cheilolejeunea intertexta (Lindenb.) Steph.

11/264. Widespread Pantropical species.

Cheilolejeunea rigidula (Nees \& Mont.) R.M.Schust.

12/291. Widespread Pantropical species.

Cololejeunea adnata Tixier (Figure 5)

06/309C, 06/310B, 08151/C, 09/240B, 13/336. Madagascar endemic, not known from other Indian Ocean islands.

Cololejeunea cuneata (Lehm. et Lindenb.) Herzog 06/309B, 10/219. A species with Asian links, scattered from all Indian Ocean islands to the Philippines and New Guinea (Tixier 1985).

Cololejeunea leloutrei (E.W.Jones) R.M.Schust. var. microlobulata Tixier

08/151B. Endemic Madagascan variety of a widespread tropical African species. 

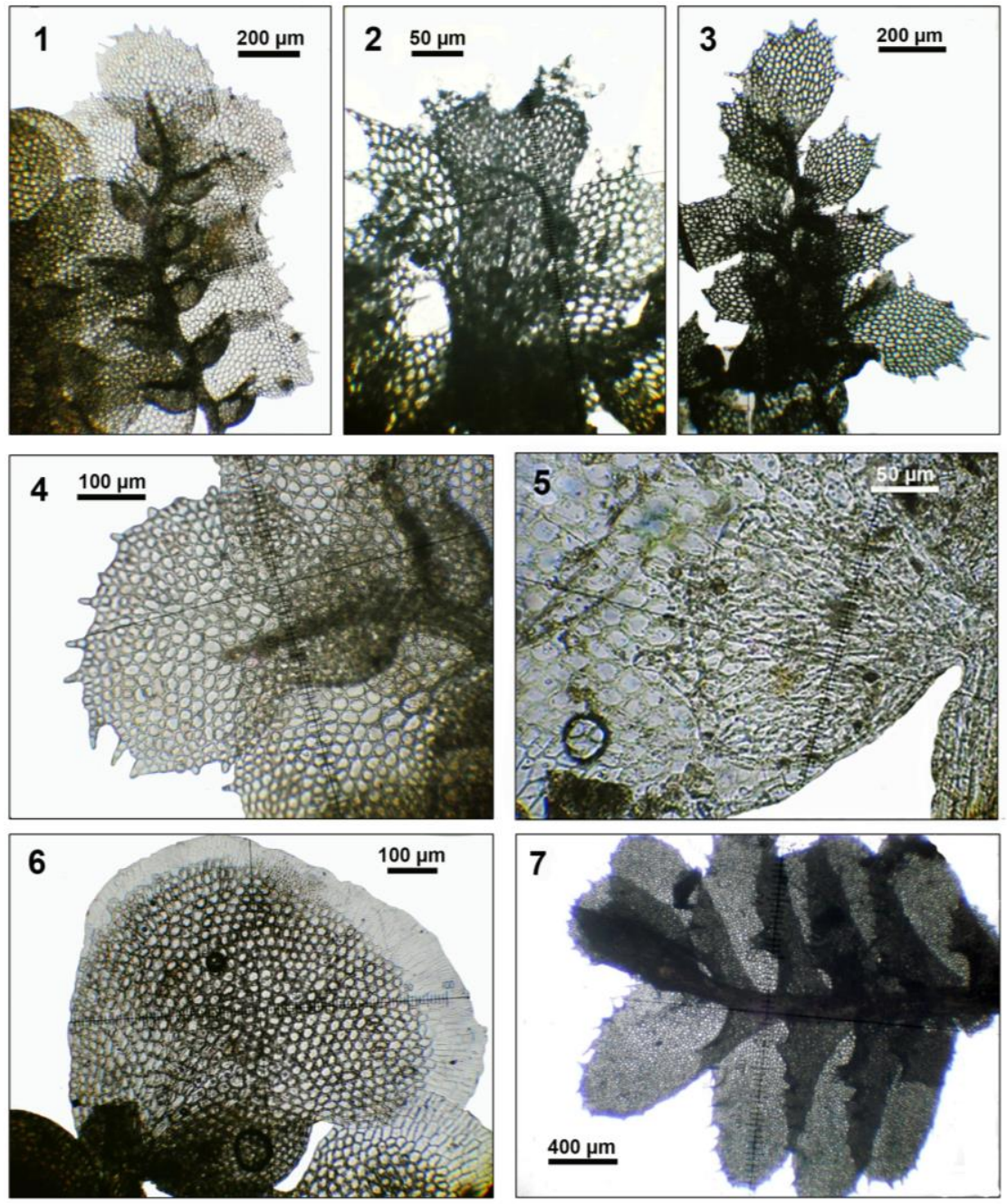

Figures 1 and 4. Capillolejeunea mascarena S.W.Arnell, 1: habit, 4: leaf, ventral views (from M.Chuah-Petiot 11/257B). Figures 2 and 3 . Cololejeunea plagiochiliana Tixier, 2: perichaetium, with mature perianth, 3: habit, ventral views (from M.Chuah-Petiot 8/151B). Figure 5. Cololejeunea adnata Tixier. Lobule with its distal end adnate to the lobe, ventral view (from M.Chuah-Petiot 8/151C). Figure 6. Cololejeunea subinflata Tixier, leaf with unusually wide hyaline margin, ventral view (from M.Chuah-Petiot 80/309). Figure 7. Plagiochila boivinii Steph. habit, ventral view (from P.Chuah-Petiot 6/166). (Microphotos by T. Pócs). 
Cololejeunea plagiochiliana Tixier (Figures 2, 3)

08/151B. A very characteristic central Madagascar endemic Hitherto known only from its type locality in the AndasibeMantadia (former Périnet) National Park (Tixier 1975, 1977).

Cololejeunea subinflata Tixier (Figure 6)

06/309, 08/151C. A central Madagascar endemic. Hitherto known only from its type locality in the Antananarivo region at Lake Mantasoa (Tixier 1977). The specimens seen in our collection has wider hyaline margin, than the type.

Cololejeunea zenkeri (Steph.) E.W. Jones

06/309A, 06/310A,B, 08/151A, 09240/A. Very widespread tropical African species.

Colura tenuicornis (A.Evans) Steph.

13/352. Widespread Pantropical species.

Diplasiolejeunea cavifolia Steph.

06/310. Widespread Pantropical species.

Drepanolejeunea madagascariensis (Steph.) Grolle

13/336. East African-Lemurian subendemic species, known from Kenya, Tanzania and from all East African islands (Grolle 1976).

Frullania diptera (Lehm.) Drège

11/269. Tropical African species.

Frullania spongiosa Steph.

06/041. Widespread tropical African species.

Lejeunea cf. angulifolia Mitt.

08/1518, 13/350B, 13/351A,13/352, 13/354/C. L. angulifolia is a rare Lemurian endemic, known only from Rodriguez Island and from the Chagos Archipelago (Seaward et al. 2006, Müller and Pócs 2002, Pócs 2011). The isotype has acuminate apex and the same lunular underleaf. Our and the later collected Chagos specimens somewhat differ, having rounded lobe apex, therefore their identity with the Indopacific Lejeunea cocoes Mitt. is also possible.

Lejeunea anisophylla Mont.

13/152, 13/350A, 13/351B, 352. Widespread Palaeotropic species (Pócs 2010). Gradstein (2021) synonymised it with the Notropical Lejeunea adpressa Nees, which needs molecular confirmation. In this case the species proves to be Pantropical. 
Lejeunea cf. isophylla E.W. Jones

13/350A. Widespread tropical African species.

Lejeunea leucosis Besch. \& Spruce

06/310A. East African-Lemurian species known from Kenya,

Tanzania, Réunion Island and Madagascar (Pócs 2010).

Lejeunea villaumei (Steph.) Grolle

11/270. Uncommon tropical African species.

Leptolejeunea maculata (Mitt.) Schiffn.

13/268. Very widespread Palaeotropical species, common all over Asia and Africa and the other Indian Ocean islands, was reported only once from Madagascar before (Pócs 2020).

Metzgeria furcata (L.) Dumort.

08/158. A common cosmopolite species not rare in the Palaeotropics.

Microlejeunea africana Steph.

04/20E. Widespread tropical African species, only slightly differs in size from the northern temperate Microlejeunea ulicina (Taylor) Steph. (Vanden Berghen 1965, Jones 1969, Schuster 1980).

Plagiochila boivinii Steph. (Figure 7)

06/166. Rare Lemurian endemic, known only from Madagascar and Réunion Island. Morphologically close to Plagiochila africana Steph. (Vanden Berghen 1981).

Pycnolejeunea contigua (Nees) Grolle

11/257A. A widespread Pantropical sun epiphyte (He 1999). Radula flaccida Lindenb. \& Gottsche

06/310. A widespread tropical African lowland species well distinguishable by its reniform, stipitate, marginal gemmae (Jones 1977).

\section{DISCUSSION}

Although the above enumeration consists only a limited number of species of a small sample, it reflects well the high diversity and peculiarity of the Madagascar flora, as more than a quarter of them are endemics, not occurring in continental Africa. Another ten are restricted to the African realm, of which only two reach the Precambrian crystalline arc of East Africa, not occurring in the interior area of the continent. 
Acknowledgements - The second author wishes to thank the Madagascar National Park Service for providing authorization to collect specimens in Zahamena National Park, to Missouri Botanical Garden (MBG), in particular, to Chris Birkenshaw MBG Antananarivo station for facilitating the collecting trip to the National Park by the second author with participating staff, to Roger L. Andriamiarisoa, Hanta Ravololonanahary and Andriamalala Rakotondrafara and last but not least, to Tamás Pócs for his valuable contribution in the identification of the epiphyllous collection.

\section{REFERENCES}

GRADSTEIN, S.R. (2021). The liverworts and hornworts of Colombia and Ecuador. Memoirs of the New York Botanical Garden 121: 1-723. https://doi.org/10.1007/978-3-030-49450-6

Grolle, R. (1976). Drepanolejeunea subgen. Kolpolejeunea - eine neue Untergattung aus der Palaeotropis. Journal of the Hattori Botanical Laboratory 40: 191-216.

HE, Q., WeI, Y-M., Pócs, T. \& ZHU, R-L. (2014). The reappraisal of Capillolejeunea S.W.Arnell (Marchantiophyta, Lejeuneaceae). Phytotaxa 175(3): 166-170. https://doi.org/10.11646/phytotaxa.175.3.7

HE, X.-L. (1999). A taxonomic monograph of the genus Pycnolejeunea (Lejeuneaceae, Hepaticae). Acta Botanica Fennica 163: 1-77.

JonES, E.W. (1969). African Hepatics XXI. Microlejeunea, Chaetolejeunea and Pleurolejeunea. Transactions of the British Bryological Society 5: 775-789.

JonEs, E.W. (1977). African Hepatics XX. The genus Radula Dumortier. Journal of Bryology 9: 461-504. https://doi.org/10.1179/jbr.1977.9.4.461

Marline, L., Andriamiarisoa, R. L., Bardat, J., Chuah-Petiot, M., Hedderson, T.A.J., Reeb, C., StrasberG, D., Wilding, N. \& Ah-PenG, C. (2012). Checklist of the bryophytes of Madagascar. Cryptogamie, Bryologie 33(3): 199-255. https://doi.org/10.7872/cryb.v33.iss3.2012.199

MülLER, F. \& Pócs, T. (2002). Contribution to the hepatic flora of Rodrigues (East African islands). Tropical Bryology 22: 107-113.

Pócs, T. (2010). On some less known Lejeunea (Lejeuneaceae, Jungemanniopsida) species in tropical Africa. East African Bryophytes, XXVII (With 9 plates). Nova Hedwigia, Beiheft 138: 99-116.

Pócs, T. (2011). Type studies of some African Lejeuneaceae. Acta Botanica Hungarica 53(1-2): 181-192. https://doi.org/10.1556/abot.53.2011.1-2.18

Pócs, T. (2020). Notes on the bryophytes of Madagascar 2. New liverwort and hornwort records. Acta Biologica Plantarum Agriensis 8: 69-84. https://doi.org/10.21406/abpa.2020.8.1.69

Reeb, C., Marline, L., Rabeau, L., Andriamanantena, A., AndriamiarisoA, R.L., Ranarijaona, H-L. \& Pócs, T. (2018). A survey of Marchantiales from Madagascar. Acta Biologica Plantarum Agriensis 6: 3-72.

https://doi.org/10.21406/abpa.2018.6.3

ReEB, C. \& GRADSTEIN, S.R. (2020). A taxonomic revision of Aneuraceae (Marchantiophyta) from eastern Africa with an interactive identification key. Cryptogamie, Bryologie 41(2): 11-34.

https://doi.org/10.5252/cryptogamie-bryologie2020v41a2 
Schuster, R.M. (1980). The Hepaticae and Anthocerotae of North America. Volume IV. Columbia University Press, New York, 1334 pp.

Seaward, M.R.D., Ellis, L.T., Pócs, T. \& WigginTon, M.J. (2006). Bryophyte flora of the Chagos Archipelago. Journal of Bryology 28: 11-19. https://doi.org/10.1179/174328206X90440

Söderström, L., Hagborg, A., Von Konrat, M., Bartholomew-Began, Sh., Bell, D., Briscoe, L., Brown, E.† , Cargill, D.C., Costa, D.P., Crandall-Stotler, B.J., Cooper, E.D., Dauphin, G., Engel, J.J., FeldberG, K., Glenny, D., Gradstein, S..R., He, X., Heinrichs, J., Hentschel, J., Ilkiu-Borges, A., Katagiri, T., Konstantinova, N.A., Larraín, J., Long, D.G., Nebel, M., Pócs, T., Puche, F., Reiner-Drehwald, E., Renner, M.A.M., Sass-Gyarmati, A., Schäfer-Verwimp, A., Segarra, J.G.M., Stotler, R.E.†, Sukkharak, Ph., Thiers, B.M., Uribe, J., Vaña, J., Villareal, J.C., Wigginton, M., ZHANG, L. \& ZHU, R.L. (2016). World checklist of hornworts and liverworts. PhytoKeys 59: 1-828. https://doi.org/10.3897/phytokeys.59.6261

TIXIER, P. (1975). Contribution a l'étude du genre Cololejeunea V. Quelques espèces de la région indopacifique. Botaniska Notiser 128: 425-431.

Tixier, P. (1977). La famille des Cololejeunoideae Grolle dans l'Océan Indien Occidental. Essai Monographique. Bulletin De L'academie Malgache 55: 173247.

TIXIER, P. (1985). Contribution à la connaissance des Cololejeuneoideae. Bryophytorum Bibliotheca 27: 1-439.

TiXIER, P. (1988). Le domaine lémuro-australasien. Intérêt biogéographique de deux espèces nouvelles. Nova Hedwigia 46 (3-4): 373-383.

VAnden Berghen, C. (1965). Hépatiques récoltées par Dr J.-J. Symoens dans la région péri-tanganyikaise (Suite). Bulletin de la Société Royale de Botanique de Belgique 98: 129-174.

VANDEn BERGHen, C. (1981). Le genre Plagiochila à Madagascar et aux Mascarenes. Bulletin du Jardin Botanique National de Belgique 51: 41-103.

Wigginton, M.J. (2018). Checklist and distribution of the liverworts and hornworts of sub-Saharan Africa, including the East African Islands. Tropical Bryology Research Reports 9: 1-138.

WIKIPEDIA (2020). Rainforests of the Atsinanana. (Accessed: 16 December 2020)

(submitted: 01.08.2021, accepted: 21.09.2021) 